\title{
Tangible and Intangible Flood damage evaluation
}

\author{
Sara Frongia ${ }^{1, a}$, Giovanni M. Sechi ${ }^{1}$ and Mark Davison ${ }^{2}$ \\ ${ }^{1}$ DICAAR Dept. of Civil and Environmental Engineering and Architecture-University of Cagliari,09123 Cagliari, Sardinia, Italy \\ ${ }^{2}$ HR Wallingford, Howbery Business Park, Crowmarsh Gifford, Wallingford, Oxfordshire OX10 8BA, UK
}

\begin{abstract}
Flooding and flash floods that cause significant economic and social damage have been widely studied in the last few decades. The European Commission Flood Directive 2007/60 Flood Risk Management Plans require the assessment of potential damage to give an appreciation of the magnitude of the consequences of a flood event and so help stakeholders to use a cost benefit approach to planning flood mitigation measures. This paper evaluates the direct tangible flood damage applying the JRC water depth-damage functions for the European territory to estimate the potential economic damage. Intangible damage is evaluated with the Life Safety Model (LSM) to study the dynamic interactions among people, vehicles, buildings and the flood wave. LSM assesses potential flood damage and allows the development of a Flood Evacuation Plan in case of an emergency, underlining the evacuation routes adopted by people and vehicles. This enables emergency managers to avoid evacuation bottleneck problems and identify areas of potential high mortality. The impact of changes such as road network improvements, the location of safe havens and timing of flood warnings can be assessed in terms of potential loss of life. The developed methodology has been applied on the Sardinian Flood Risk Management Plan pilot basin, the Coghinas river lowland basin.
\end{abstract}

\section{Introduction}

Recent flash flood events have caused significant damages in the Mediterranean area highlighting the importance of studies related to Flood Directive 2007/60 in these regions. Climate change increases the unpredictability of the flood events leading the monitoring organisation of each European country to predispose or improve their Flood Risk Management Plan, as required in the European Flood Directive. In addition to climate change, the current trend of people moving from rural areas to cities increases urbanization and as a consequences an emergency or disaster management plan is necessary in terms of preparation, support and reconstruction when natural or man-made disasters occur[1].

This paper applies methodologies to estimate the flood potential economic damages in the Sardinian area. In recent decades major flood events have hit the territory causing enormous economic damages, loss of life and injuries. Moreover, hydraulic analysis and evacuation plans are developed to increase awareness of the flood risk and hence limit life losses.

A Research Team from the University of Cagliari has been working with the Sardinian Hydrographic District Authority and the Civil Protection Agency in the development of the Sardinian Flood Risk Management
Plan (FRMP). One of the main tasks considered in FRMP is the update of the Flood Hazard Maps of the whole island area defined in the Sardinian Flood and Geological Risk Plans: Hydro-geological System Plan (PAI)[2] and Fluvial Zones Definition Plan (PSFF)[3]. These maps provide the basis for identifying appropriate measures to mitigate the flood risk in the FRMP. The maps are, in fact, instruments not just for defining and communicating flood risks, but mainly, to regulate territory uses rationalising the inevitable limits and failures of controls and providing awareness of the potential floodplain area[4]. The resulting flood maps are the launch pads to start the flood assessment of the potential flood damage estimation that give an order of the magnitude of the consequences of the flood event [5]. In contrast with engineered defences designed to keep water away, it is important to understand potential consequences and help communities to become more resilient and adapt to changing levels of flood risks [4].

Previous studies indicate that the majority of researchers have classified damage in two groups, tangible and intangible damage. Furthermore, each group of damage is split in to two groups, direct and indirect, depending on the direct contact with the water. For example the direct damages result from the physical contact of flood water with property and its contents [8]. Many items of flood damage loss are a function of the

\footnotetext{
a Corresponding author: frongiasara@tiscali.it
} 
nature and extent of the flooding, including its duration, velocity and contamination of the flood water by sewage and contaminants [8], Table 1 .

\begin{tabular}{|c|c|l|l|}
\hline \multicolumn{2}{|c|}{} & \multicolumn{2}{c|}{ Measurement } \\
\cline { 3 - 4 } \multicolumn{2}{|c|}{} & Tangible & $\begin{array}{c}\text { Intangible } \\
\text { (difficult to quantify) }\end{array}$ \\
\hline $\begin{array}{c}\text { Form } \\
\text { of } \\
\text { Loss }\end{array}$ & Direct & $\begin{array}{l}\text { Damage to } \\
\text { building and } \\
\text { contents }\end{array}$ & $\begin{array}{l}\text { Loss of an } \\
\text { archaeological site }\end{array}$ \\
\cline { 2 - 4 } & Indirect & $\begin{array}{l}\text { Loss of } \\
\text { industrial } \\
\text { production }\end{array}$ & $\begin{array}{l}\text { Inconvenience of } \\
\text { post-flood recovery }\end{array}$ \\
\hline
\end{tabular}

Table 1. Direct, indirect, tangible and intangible flood impacts (Chapter 3 MCM Handbook [8])

The "Comparative Flood Damage Model Assessment" shows seven of the models available so far to evaluate the direct tangible damage: FLEMO, Damage Scanner, Rhine Atlas, Flemish Model, Multi-Coloured Manual (MCM), HAZUS-MH and JRC Model [5, 6]. All of these models appreciate the direct tangible damage due to the flood water depth.

The present research analyses the area of a pilot basin of the Sardinian FRMP: the Coghinas river lowland valley basin. In the first stage of the study a monodimensional hydraulic model has been developed with the USACE software HEC-RAS [14]. The JRC Model Methodology [15] was applied to the floodplain, using water depth-damage functions to evaluate the potential flood direct tangible damage in order to define flood mitigation protection works according with an economic efficiency planning.

The analysis has been improved through simulating flood inundation with a two-dimensional hydraulic model (RFSM-EDA) in the second stage of the project. A two-dimensional model was necessary to assess the intangible damage and to prepare an evacuation plan with the Life Safety Model (LSM). LSM is a dynamic agent based model that estimates the flood risk to people in terms of loss of life and injuries, evacuation times and improvements in emergency planning [7].

\section{Studied Case: Coghinas river lowland valley basin}

The PSFF, the Sardinian hydro-geological plan, defines the territory managed by seven river system basins, Figure 1, and for each basin the main river and their tributaries were hydraulically and geologically analysed to identify the hazard areas, represented respectively with blue and green colours in Figure 1. Following the methodology developed for the PSFF, the Coghinas river lowland valley basin has been here hydraulically analysed for three events characterised by return periods of 1 in 50, 1 in 100 and 1 in 200 years[9]. The Coghinas river drains a $2453 \mathrm{Km}^{2}$ catchment along $115 \mathrm{Km}$ of main river. Along the river two main dams, Muzzone and Casteldoria dams, regulate the flows in the catchment. The Muzzone reservoir, of $254 \mathrm{M} \mathrm{m}^{3}$ volume, is located in the upstream of the Coghinas river, while the Casteldoria reservoir with a volume of $4.5 \mathrm{M} \mathrm{m}^{3}$ is located $15.9 \mathrm{Km}$ from the river mouth that emerges in the Gulf of Asinara. The main function of the Casteldoria dam is the diversion of water to users centres, whereas the Muzzone dam can reduce flood-peak flows. The lower part of the Coghinas river, from the Casteldoria dam to the outlet, is known as Coghinas river lowland valley basin and this is the area under analysis for the present research.

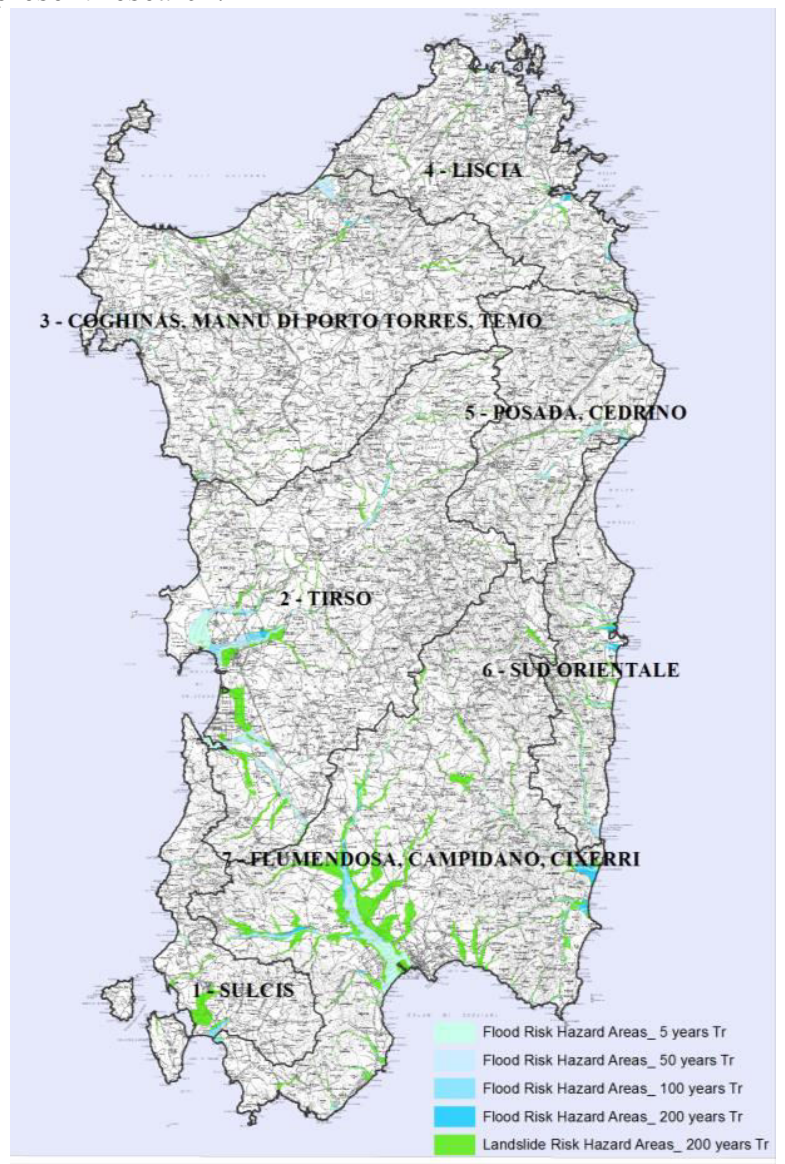

Figure 1. Sardinian Hydrographic Basins and Flood Hazard Maps according with the PSFF.

The Coghinas river lowland valley area is managed by four council regions: Viddalba, Santa Maria Coghinas, Valledoria and Badesi. Information was collected about the spatial distribution habitable buildings and the residential and tourist component of the population in the area potentially flooded. Each town consists of different types of building structures among dwelling, public offices, commercial, industrial and tourist buildings, as shown in Figure 2.

Viddalba town consists of 822 building hosting 1726 residents. The Santa Maria Coghinas town is defined by 700 structures where a component of 1436 residents is located and the tourist population could reach a maximum of 245. The Badesi town, located out of the potential floodplain risk area, owns the resort area of Baia delle Mimose built near the mouth of the Coghinas river on the right hand side of the river. The maximum number of tourists in Baia delle Mimose resort is estimated as 1521 and they would stay in 317 tourist accommodation units. The Alert Operating Instructions of the Sardinian Civil Protection Agency[10] identify 74 
resort buildings in the suburban area of the Badesi town as potential shelters for flood emergency evacuation. Valledoria town has 1051 structures that could host 3223 people including both residents and tourists. A second part of the tourist population in the Valledoria area could be accommodated in the camping area known as $\mathrm{La}$ Foce, which is located near the mouth of the Coghinas river on the left hand side. This area is of particular interest for the study because of the potentially dangerous location. La Foce camping area consists of 408 vulnerable structures; tents, mobile homes, campers and bungalows, where 1204 tourists could sojourn.

A complete analysis of the studied area shows a total of 3372 buildings distributed in the area that could host a maximum number of 9450 people between residents and tourists, as shown in Table 2.

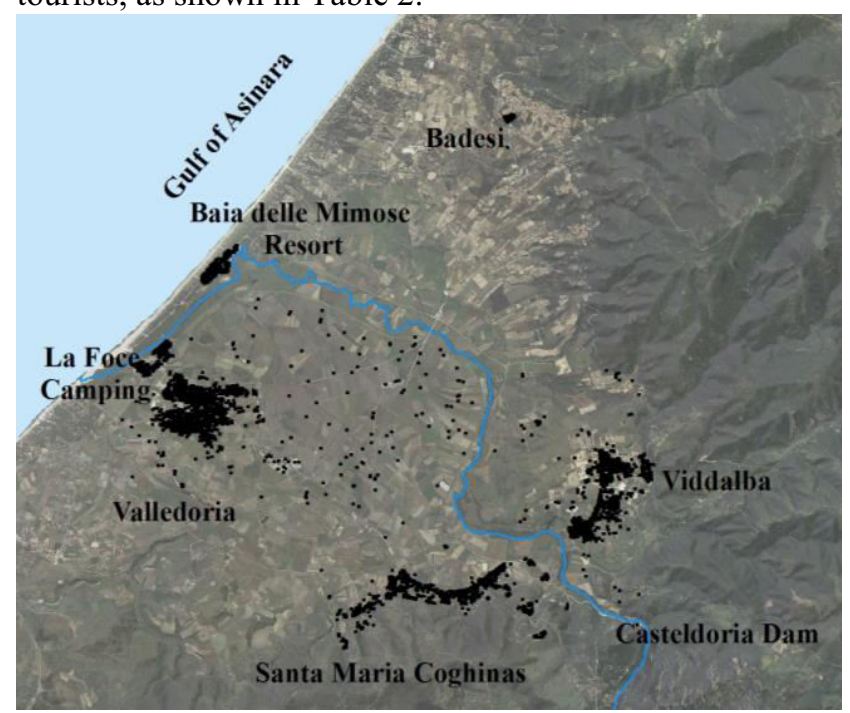

Figure 2. Coghinas river lowland valley area and building distribution

\begin{tabular}{|l|c|c|}
\hline \multicolumn{1}{|c|}{ Town } & $\begin{array}{c}\text { Number of } \\
\text { Buildings }\end{array}$ & $\begin{array}{c}\text { Number of } \\
\text { People }\end{array}$ \\
\hline Viddalba & 822 & 1742 \\
\hline $\begin{array}{l}\text { Santa Maria } \\
\text { Coghinas }\end{array}$ & 700 & 1681 \\
\hline $\begin{array}{l}\text { Badesi-Baia delle } \\
\text { Mimose Resort }\end{array}$ & 391 & 1521 \\
\hline Valledoria & 1051 & 3223 \\
\hline La Foce Camping & 408 & 1204 \\
\hline \multicolumn{1}{|c|}{ Total } & 3372 & 9450 \\
\hline
\end{tabular}

Table 2. Building and People samples on the Coghinas river lowland valley basin

\section{JRC Model and direct tangible damage evaluation}

\subsection{JRC Model}

The economic evaluation of flood damage is based, by the majority of researchers, on the application of flood depth-damage functions. Herein, the JRC Model has been applied and slightly changed in respect of the baseline model described in the "Flood damage functions for EU member states"[11]. The JRC Model curves are the result of an analysis and elaboration of data collected from flood events that hit European Member States before 2007. This data was analysed to produce harmonised water depth-damage curves applicable for each European Country to assess the direct tangible flood damage. The JRC Model flood damage functions show that economic damage increases proportionally with the water depth increment in a range of water depth between zero and six metres. Moreover each group of damage functions are divided into five different groups considering the different land uses of the territory. The five macro-categories of land uses are: Residential buildings, Commercial, Industrial, Agricultural, Infrastructure and Road. Therefore the potential direct tangible damage from a flood event could be calculated knowing water depth level from the flood hazard maps in the area under analysis, how the land of the area is used in order to relate the maximum economic value of the damage and the relative depth-damage function for each land use category.

The present research, using the JRC relative depthdamage functions, required two main changes considering the Sardinian territory and the characteristics of flood events that have hit the area to date.

The first modification concerns the water depth range of the function development. The maximum value of 6 metres of water depth has been decreased by 1 meter, as shown in Figure 3, meaning that the maximum flood damage value is now assigned for water depth equal to or higher than 5 metres.

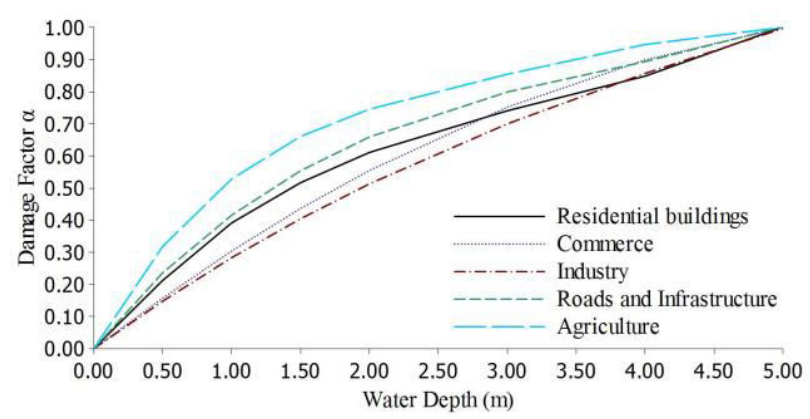

Figure 3. Flood Damage Approximated Harmonise Functions for EU Member States [11] with changes of water depth range.

A second modification considers the JRC methodology regarding the land use subdivision and the update of the Corine Land Cover for the Sardinian territory. The five macro categories of the JRC Model have been seen as too restrictive for describing Sardinian territory which led researchers to increase the original 
groups of macro categories from five to twelve. The new land use category list takes into account the land use type that would be subjected to direct tangible damage and, even more, defines protected areas (i.e. environmental heritage areas, historical heritage areas, etc.) and water bodies for which it is not already possible to assign a Maximum Damage Value because of the lack of information defining an economic value for damage. Therefore, these land use macro categories ( the last four groups in Table 4) have been set without defined a Maximum Damage Value to exclude them from the direct damage calculation and identify the areas where the flood can cause intangible damage (Table 3) [9].

\begin{tabular}{|l|c|c|}
\hline \multicolumn{1}{|c|}{ Land Use Category } & Label & $\begin{array}{c}\text { Maximum } \\
\text { Damage } \\
\text { Value (€/m²) }\end{array}$ \\
\hline Residential Buildings & $\mathrm{R}$ & 618 \\
\hline Commerce & $\mathrm{C}$ & 511 \\
\hline Industry & $\mathrm{I}$ & 440 \\
\hline Agriculture & $\mathrm{A}$ & 0.63 \\
\hline Council Roads & $\mathrm{N}$ & 10 \\
\hline Provincial Roads & $\mathrm{P}$ & 20 \\
\hline Other Roads & $\mathrm{S}$ & 40 \\
\hline $\begin{array}{l}\text { Areas with water supply } \\
\text { network, electricity grid and } \\
\text { similar systems }\end{array}$ & $\mathrm{T}$ & 40 \\
\hline Lakes, rivers and similar areas & $\mathrm{H}$ & - \\
\hline Environmental heritage areas & $\mathrm{J}$ & - \\
\hline $\begin{array}{l}\text { Historical and archaeological } \\
\text { heritage areas }\end{array}$ & $\mathrm{K}$ & - \\
\hline $\begin{array}{l}\text { Area subjected of other } \\
\text { intangible damages }\end{array}$ & $\mathrm{X}$ & - \\
\hline
\end{tabular}

Table 3. Land use Categories and related Maximum Damage Value for Sardinian Region

\subsection{D Hydraulic simulation and flood direct tangible damage computation}

The flood risk situation of the Coghinas river lowland valley basin has been studied with the mono dimensional hydraulic software HEC-RAS, considering the main flood risk scenarios defined in the PSFF. The PSFF required a flood risk analysis for return periods of 1 in 50,1 in 100 and 1 in 200 years where the boundary conditions are provided[5]. The results obtained with a 1 meter resolution have been rearranged to obtain a shape file defined by cells of $3 \times 3$ metres (due to reduce, in a second step, elaboration time computing the economic damage) define the floodplain extent and to give the maximum water depth for each cell in the map, Figure 4.

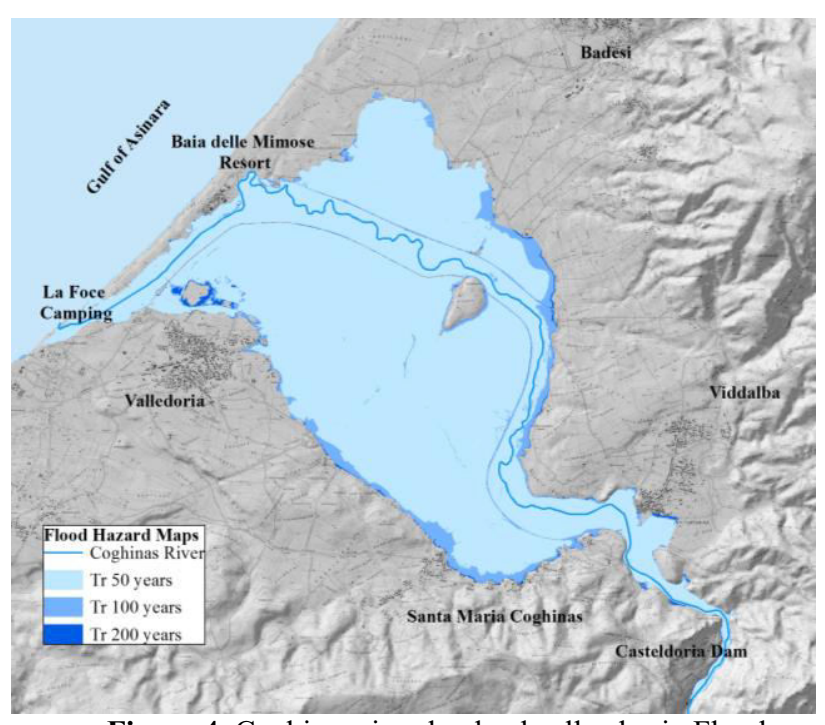

Figure 4. Coghinas river lowland valley basin Flood Hazard Maps and urban centers

The flood hazard maps are the basis with which to compute the flood direct tangible damage with the JRC Model that has been chosen at this study level of the flood damage evaluation. First of all the land use characteristic of each cell was defined in order to couple this information with the appropriate relative water depth-damage function. At this point it is necessary to know the maximum water depth level reached in every cell using the flood hazard maps. All of these information are then used to defined the appropriate $\alpha$ coefficient and the proper maximum flood damage value $\left(€ / \mathrm{m}^{2}\right)$ applying the JRC Model water depth-damage functions to evaluate the direct tangible damage for each cell.

The flood event of 1 in 200 years return period, was the worst among the three events analysed in terms of flood extent and water depth. The JRC Model has been applied on the flooded area giving back resulting damages. Table 4 shows total economic damages and total damaged area for each land use category defined for the Sardinian territory, in Table 3. This analysis enables identification of areas that suffer highest damage may benefit most from potential intervention measures.

\begin{tabular}{|c|c|c|}
\hline $\begin{array}{c}\text { Land Use } \\
\text { Category Label }\end{array}$ & $\begin{array}{c}\text { Damaged Area } \\
\mathbf{( m}^{\mathbf{2}}\end{array}$ & Damage ( $\boldsymbol{(})$ \\
\hline A & $13,319,222$ & $6,019,251$ \\
\hline C & 42,396 & $10,304,961$ \\
\hline I & 73,184 & $10,950,897$ \\
\hline J & $2,119,113$ & - \\
\hline K & 40,014 & - \\
\hline N & 45,786 & 232,406 \\
\hline P & 111,261 & $1,137,800$ \\
\hline R & 148,135 & $37,856,384$ \\
\hline T & 220,499 & $4,504,593$ \\
\hline X & 673,836 & - \\
\hline Total & $\mathbf{1 6 , 7 9 3 , 4 4 6}$ & $\mathbf{7 1 , 0 0 6 , 2 9 2}$ \\
\hline
\end{tabular}

Table 4. Potential damaged area and damages in Coghinas River lowland valley basin - Present situation $\operatorname{Tr}=200$ years 


\section{2D Hydraulic Analysis and Evacuation Plan}

JRC Model enables computation of the direct tangible damage in economic terms but not an evaluation of the intangible damage, unless an idea of the damaged area extent has been given for protected or natural areas. At this step it was necessary to identify a method to assess the intangible damage. The study identified the Life Safety Model (LSM) as a tool that could compute the potential loss of life, interpreted as intangible damage, and to define an evacuation plan in case of flood emergency in the studied area. The loss of life evaluation is a relevant aspect under interest of the Sardinian Hydrographic District Authority and the Sardinian Civil Protection Agency. Because without a proper evacuation plan, the recent considerable event which happened in November 2013, Cleopatra hurricane, caused a death toll of 13 and $60 \mathrm{M} €$ of direct tangible damage in Olbia town, located in the North East coast of Sardinia.

The creation of a Flood Evacuation Plan requires the collection of data on demographic people distribution, building distribution and road network in the area under analysis. In addition the LSM module to compute loss of life works using a two-dimensional hydraulic model to properly describe the spatial and temporal variations in water depth and velocity.

\subsection{D Hydraulic Simulation: RFSM-EDA application}

The two-dimensional hydraulic simulation has been obtained with RFSM-EDA, a computational engine for the simulation of inundations that it is able to provide depth and velocity outputs with short simulation runtimes[12].

RFSM-EDA requires a pre-processing tool to create the computational mesh grid. AccData is the pre-process tool that, through the key topographic features as crests and low points defined in a DTM input, provides the computational mesh grid required by RFSM-EDA.

The cells, called Impact Cells, are assembled by connecting the lines of greatest slope to determine group of cells which all flow to the same topographic low point and so create the Impact Zones necessary to develop the hydraulic simulation. AccData has been configured to create Impact Zones (IZ) with a size between 1'000 $\mathrm{m}^{2}$, IZ Minimum Size, and $10^{\prime} 000 \mathrm{~m}^{2}$, IZ Maximum Size. These parameters have been run with a DTM of 10 metres resolution to obtain a mesh grid in the WGS84 UTM Coordinate Reference System with output values assigned in metres [12].

Once that the Impact Zones had been assembled to obtain a proper RFSM Traditional mesh grid, the hydraulic boundary conditions and the surface roughness have been implemented as assigned for the Coghinas river lowland valley basin by the PSFF.

Herein the hydraulic model of the event characterised by a 200 years Return Period is described. The PSFF considers, as upstream boundary condition in correspondence of the Casteldoria dam, a water flow discharged rate that follows a hydrograph schematized by a triangular shape. The event reaches the maximum flow discharged rate of $4460 \mathrm{~m}^{3} / \mathrm{s}$ at 9.9 hours and with a lag time of 26.3 hours. The downstream boundary condition defines a free water surface of 1.8 metres above the standard sea level. Moreover, the boundary conditions have been updated with the Manning roughness coefficient of the riverbed and adjacent area[9]. RFSMEDA produces a two-dimensional hydraulic output that confirms the results already obtained running HEC-RAS. In fact, the floodplain extents and the maximum water depths obtained from the two methods are similar. HECRAS estimates a water depth range between 0 and 14.25 metres, while RFSM-EDA water depth values are between 0 and 14.93 metres, as shown in Figure 5.

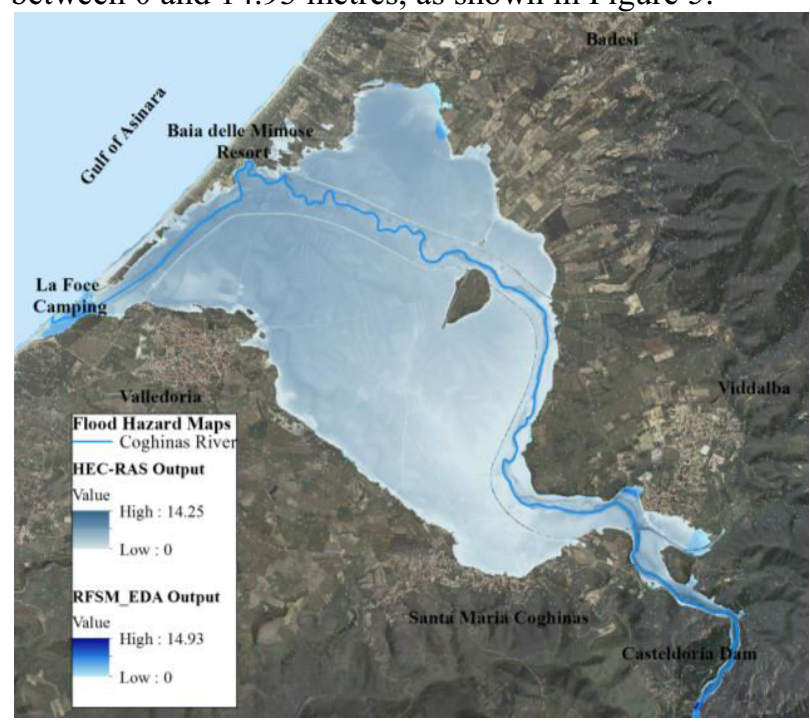

Figure 5. Comparison of the RFSM-EDA and HEC-RAS maximum water depth value maps

In addition the two-dimensional hydraulic model simulates the propagation of the flood across the floodplain. The flood simulation shows the capacity of the levees to contain the flood for the first 2.5 hours of the event. Gradually after 3 hours the right river bank starts to be overflowed, while the agricultural area beyond right embankment are at the beginning of the inundation. At 3.5 hours the simulation shows relevant damages in the left river bank especially in the La Foce Camping area and the suburban area of Valledoria town. Finally at 5 hours the Baia delle Mimose Resort area is flooded. The analysis underlines that the study area could be damaged before the flood reaches the peak of the event.

\subsection{Evacuation Plan: Life Safety Model (LSM)}

LSM provides a method to develop evacuation plans and to compute the intangible component of the flood damage (in particular loss of life). Working also as support tool for the Civil Protection Agency, LSM helps planning the flood emergency situation.

Figure 5 shows the virtual world created to describe the situation of the receptors in the area under study. The receptors are mainly interpreted in terms of buildings, people (Population at Risk Unit, PARU) and road 
network distribution. Moreover LSM requires information about how the persons are related each other creating groups (Population at Risk Group, PARG), how groups of people could evacuate the hazard area to reach the safe heavens (walking or driving). The flood warning and evacuation issuance have been included in the model using the actual locations, defined as warning points (Casteldoria dam and council offices of Viddalba e and Valledoria towns). LSM uses a generalised event logic to determine the location of each object, its behaviour in case of flood risk (aware, trying to reach the safe heaven, the behaviour encountering the flood wave) and, with a loss function related to each receptors, specifies the ability of the receptor to resist the impact from the flood wave. This is implemented in virtual world by setting parameters that represent the strength limits of the receptor and the water depth limit of each building, vehicle, person (generally a human starts to be unstable around 0.30 metres of water depth and the mobility is allowed till a water depth around the chest, more or less the $70 \%$ of the person height)[7]. LSM relates the water depth and velocity with the elements of the "virtual world" at each time step simulating the potential behaviour of each element of the model that could stand or could be overcome by the flowing water.

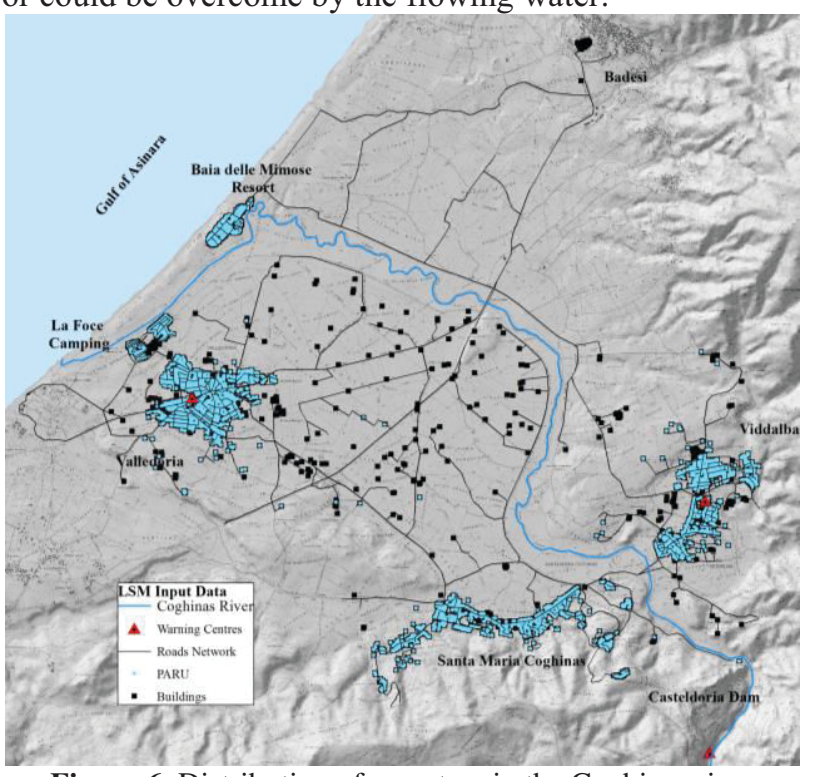

Figure 6. Distribution of receptors in the Coghinas river lowland valley basin

The Coghinas river lowland valley basin model has been set considering a uniform distribution of resident people in dwellings, while the La Foce camping and Baia delle Mimose resort, as tourist areas, are considered fully booked. The LSM has been run a number of times to compare outputs of different scenarios. The first scenario considers that the people are not aware of the event and in this way the evacuation starts when the water level reaches 0.20 metres at the location of each individual or group. In a second step the analysis was developed considering the mobilization of the persons located within 500 metres from the floodplain boundary and the warning issuance has been stepped, scenario by scenario, in increments of 20 minutes from 3 to 6 hours prior to the peak of the event in order to estimate the impact on numbers of fatalities with improving the flood alert system. The chart in Figure 6 shows potential fatalities of 806 when the evacuation alarm is not sent and people have to decide if to evacuate or not as soon they realise about the flood situation. There is a gradual decrease in the potential number of fatalities as the time available between the flood evacuation issuance and the arrival of the flood wave increases. In fact the number of fatalities is reduced to 34 (mainly in the touristic area near the mouth of the river), if the evacuation issuance is set at 6 hours prior to the peak of the event, and it is eliminated if the warning is issued 6,33 hours prior to the peak of the event. In Figure 6 a second curve is plotted to show the impact of a 1 hour delay in the response of people to the evacuation warning on the number of fatalities. The trend does not change in that the number of fatalities reduce as the lead time of the warning increases. Although, as the response time increases the warning lead also needs to increase to reduce the potential number of fatalities.

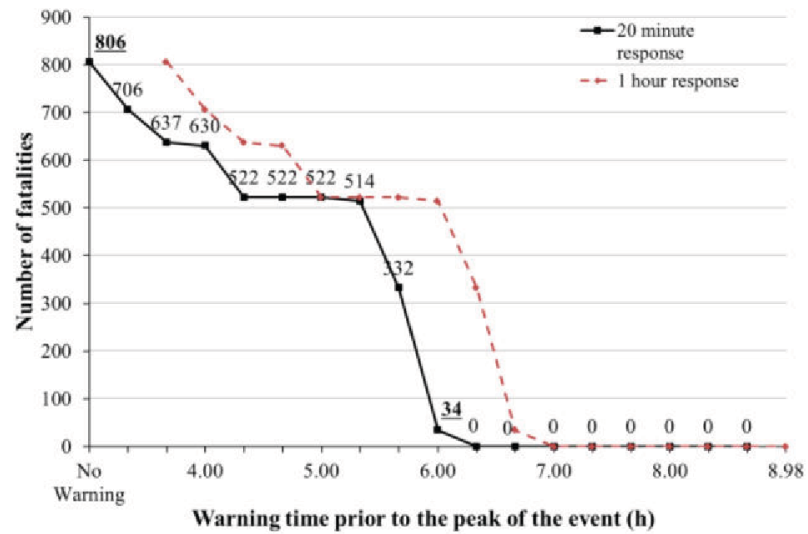

Figure 7. Evaluation of the potential loss of life in the Coghinas river lowland valley basin for different flood warning and response scenarios

The attention of LSM outputs analysis is focused on the death toll but the software also analyses building and vehicle behaviour, gives an idea of the potential tangible loss. The results showed that the building performance does not change considering that their resistance could not be improved scenario by scenario and that could change only modifying water depth and velocities. Vehicle loss decreased with improving the lead time of issuing warnings because people have more time to reach the safe heaven and also reduce potential goods loss.

\section{Conclusion}

The JRC Model and LSM software offer useful outputs for the evaluation of residual flood risk and the assessment of the flood consequences in terms of potential flood damage. A review of the European situation in terms of flood risk shows that although the deadline for the Flood Risk Management Plan required by the Flood Directive 2007/60 has been reached, an update of the Flood Risk Management Plans is required every six years. The continuous improvement of the Plan leads every Hydrographic Basin authority to fulfil the planned mitigation measures and provide new methodologies to prevent loss caused by residual risks. 
At the end of September 2015 a Mediterranean cyclone hit the Western area of the Mediterranean sea threatening huge damages, and in particular caused significant loss in the French Riviera. This also happened in Sardinia during the Cleopatra cyclone in November 2013. In both cases a part of the economic damages and the death toll could potentially be contained with an appropriate emergency evacuation plan. These events underline the necessity to improve people preparedness in case of flood emergency with a proper plan to identify where and how people should reach a suitable safe heaven.

\section{References}

1. Vojinovic Z. and R.K. Price (2008). Urban flood disaster management. Urban Water Journal, 5(3), 259-276

2. RAS- Sardinian Regional Commission (2008). Piano di Assetto Idrogeologico (P.A.I.). Cagliari

3. RAS- Sardinian Regional Commission (2013). Piano Stralcio Fasce Fluviali (P.S.F.F.). Cagliari

4. Demeritt D. and Porte J. (2012). Flood-risk management, mapping, and planning: the institutional politics of decision support in England Environment and Planning Vol. 44, 2359-2378

5. Frongia S. et al. (2015). Flood Damage Risk Assessment Optimizing a Flood Mitigation System. Proceedings of the $9^{\text {th }}$ World Congress of the European Water Resources Association (EWRA) Conference, June 10-13, Istanbul

6. Jongman B., et al. (2012). Comparative flood damage model assessment: towards a European approach. Natural Hazards Earth System Sciences: 12, 3733-3752, doi:10.5194/nhess-12-3733-2012

7. Lumbroso D.M. and Tagg A.F. (2011). Evacuation and loss of life modelling to enhance emergency response. Proceedings of the International Symposium on Urban Flood Risk Management, Graz, Austria, 21-23 September 2011

8. Penning-Rowsell E. et al. (2005). The Benefits of Flood and Coastal Risk Management: A Handbook of Assessment Techniques. Middlesex University Press ISBN 1904750516

9. Frongia et al. (2015). Flood Risk Management Plan for the Sardinia Hydrographic District. Proceedings of the $9^{\text {th }}$ World Congress of the European Water Resources Association (EWRA) Conference, June 10-13, Istanbul
10. RAS- Sardinian Regional Commission (2014). Manuale Operativo delle allerte ai fini della Protezione Civile. Cagliari.

11. Huizinga H.J. (2007) Flood Damage Functions for EU member states. HKV Consultants, Technical report implemented in the framework of the contract \#382441-FISC awarded by the European Commission - Joint Research Centre

12. HR Wallingford (2013). Guidance for the use of RFSM_EDA and AccData. HR Wallingford

13. Carvajal C., Peyras L., Arnaud, P., Boissier D. and Royet P. (2009). Probabilistic Modeling of Floodwater Level for Dam Reservoirs, Journal of Hydrologic Engineering, 14(3), 223-232

14. USACE (2010). HEC-RAS River Analysis System

15. HKV Consultants (2007). Flood Damage Functions for EU member states. Final report for JRC Institute for environment and sustainability 